\title{
Xanthone as Antimalarial: QSAR Analysis, Synthesis, Molecular Docking and In-vitro Antimalarial Evaluation
}

\author{
JUFRIZAL SYAHRI ${ }^{1,2 *}$, EMMY YUANITA ${ }^{2,3}$, BETA ACHROMI NUROHMAH ${ }^{2}$, \\ MUHAMMAD HIZBUL WATHON ${ }^{4}$, RAHMADINI SYAFRI ${ }^{1}$, \\ RIA ARMUNANTO² and BAMBANG PURWONO2*
}

\begin{abstract}
${ }^{1}$ Department of Chemistry, Universitas Muhammadiyah Riau - Indonesia.
${ }^{2}$ Department of Chemistry, Universitas Gadjah Mada - Indonesia.

${ }^{3}$ Department of Chemistry, Universitas Mataram - Indonesia.

${ }^{4}$ School of Chemistry, University of Leeds - United Kingdom.

${ }^{*}$ Corresponding author E-mail: purwono.bambang@ugm.ac.id
\end{abstract}

http://dx.doi.org/10.13005/ojc/330104

(Received: October 25, 2016; Accepted: January 01, 2017)

\begin{abstract}
The rational design of eighteen new antimalarial compounds from xanthone derivatives has been conducted based on Quantitative Structure-Activity Relationship (QSAR) calculation using semiempirical AM1 methods. The best equation model obtained from QSAR calculation was Log $p \mathrm{IC}_{50}$ $=2.997-29.256$ (qO8) - 138.234 (qC9) - 6.882 (qC12) - 107.836 (qC14) + 48.764 (qO15). Among the designed compounds, 3,6-dihydroxy-9H-xanthen-9-one (26) and 3,4,6-trihydroxy-9H-xanthen9-one (27) have been synthesized and investigated their in-vitro antimalarial activities against the chloroquine-sensitive 3D7 strain. An in-vitro antimalarial activity of compound 26 and 27 showed to be highly potential as antimalarial compounds with $\mathrm{IC}_{50}$ of 0.71 and $0.11 \mu \mathrm{M}$ respectively. Molecular docking studies of compound 26 and 27 showed the formation of a binding interaction between the compounds with the amino acids Ala16, Ser108, Phe58, Asp54 and Leu46, which is the crucial amino acids for antimalarial activity based on the protein-ligand co-crystal structure of WR99210 (1,3,5-triazine, a pre-clinical molecule as $P$. falciparum DHFR-TS inhibitor).
\end{abstract}

Keywords: Antimalarial, Docking, Semi-empirical AM 1, QSAR, Xanthone.

\section{INTRODUCTION}

There are five types of malaria parasites that commonly infect humans, the first one is Plasmodium falciparum, which is the most fatal among other Plasmodium parasites. Furthermore, Plasmodium vivax, Plasmodium ovale, and Plasmodium malariae that cause mild diseases in human and not generally fatal. The fifth parasite, Plasmodium knowlesi, is known to cause malaria in monkeys, which is reported can also infect humans. According to the WHO report in 2015, mortality number caused by malaria disease of as many as 438,000 lives from 214 million cases of malaria infection in the world. ${ }^{1}$ 
Parasite resistance to the antimalarial drugs such as chloroquine and artemisinin has led to the high number of dead. ${ }^{2-3}$ In order to prevent more victims caused by malaria disease, searching and finding for new candidates of the antimalarial drug must be conducted continuously because the absence of new antimalarial drugs may cause malaria being an uncured disease in the next ten years. One of the strategies to find new antimalarial drugs is to explore natural products, particularly from plants, which have been traditionally utilized as an antimalarial drug. Xanthone, as one of the secondary metabolite compounds from nature, has been reported to have antimalarial activity.4-6 However, further research to find optimum antimalarial activities of xanthone compounds is still needed. Hence, the research to discover xanthone compounds with the best antimalarial activity should be conducted.

Xanthone compound was also reported for having some activities as anticancer, ${ }^{7-9}$ antitumor, ${ }^{10-}$ ${ }^{11}$ antioxidant, ${ }^{12-13}$ cytotoxic, ${ }^{14-16}$ leukemia, ${ }^{17}$ antidiabetic. ${ }^{18}$ These facts show that xanthone has tremendous potential activities. In general, the reported compounds were the result of the isolation process, which means it is more difficult to conduct further development in enhancing the activity because of the low yield of compounds afforded. Therefore, the research that can truly maximize the potential of the xanthone compound is required, such as by making design and synthesis of xanthone compounds that have optimum activity. This kind of research could generate higher yield of the compounds obtained and further modification and their biological activity assay can be conducted effectively.

QSAR analysis of xanthone as an antimalarial has been reported by Amanatie et al (2010) ${ }^{19}$. They have used PM3 method and concluded the descriptors which influence the antimalarial activity were atom charges of $\mathrm{O} 7, \mathrm{C} 12$, and $\mathrm{C} 13$. However, their research did not report the design of xanthone which had the best antimalarial activity.

In this research, QSAR studies were carried out to determine the descriptors which were responsible for the antimalarial activity. QSAR equation from the resulted descriptor was used to design new xanthone compounds which have the best-predicted antimalarial activity. Actually, QSAR studies could help to determine what the functional group should be attached to the compounds in order to get the best activity. Herein, molecular docking with the crystal structure (1J3I.pdb) of Plasmodium falciparum dihydrofolate reductase-thymidylate synthase (DHFR-TS) was conducted to observe the binding interaction of the xanthone with the amino acid. The designed compound was further synthesized and their in vitro antimalarial activity was tested to prove the accuracy of QSAR calculation.

\section{MATERIALS AND METHODS}

\section{Data Set}

In QSAR study, data sets used were 25 reported prenylated xanthone derivatives with its antimalarial activity as seen in Table $1 . .^{20-21}$. This data set was divided into two parts i.e. internal evaluation (training set) and external evaluation (test set). The test set compounds were selected manually in order to consider the structural diversity and a wide range of antimalarial activity. The in vitro antimalarial activities expressed as the inhibition concentration $\left[\mathrm{IC}_{50}\right.$ $(\mu \mathrm{g} / \mathrm{mL})]$ values were converted to the logarithmic $\mathrm{pIC}_{50}=\log \mathrm{IC}_{50}$ and used as dependent variables in QSAR analysis.

\section{Instrumentation}

In this study a PC with Intel $(\mathrm{TM}) 2$ Quad CPU Q8200 @2.33GHz was running under a Windows XP Professional operating system. All quantum mechanical calculation was executed using Gaussian 09 software. Correlation of QSAR models was evaluated by multiple linear regression analysis using SPSS statistics 23.0. Docking studies were performed with the cDOCKER protocol under the receptor-ligand interaction section in Discovery Studio 3.1 (Accelrys, Inc., San Diego, CA, USA). Other molecular modeling software was used throughout this study including CHIMERA 1.9 and ChemOffice $\circledast$.

The melting point of the synthesized compounds was determined using Electrothermal 9100 with temperature gradient $10^{\circ} \mathrm{C} / \mathrm{min}$. ESI-HRMS spectra were recorded on a Bruker micrOTOF Mass Spectrometer. Meanwhile, ${ }^{1} \mathrm{H}$ and ${ }^{13} \mathrm{C}-\mathrm{NMR}$ spectra were recorded on a JEOL $500 \mathrm{MHz}$ spectrometer with TMS as an internal standard. All reagents were 
Table 1: Xanthone derivatives compound used as data set for QSAR analysis

\begin{tabular}{|c|c|c|c|c|c|c|c|c|}
\hline Comp & $R_{1}$ & $\mathbf{R}_{2}$ & $\mathbf{R}_{3}$ & $\mathbf{R}_{4}$ & $\mathbf{R}_{5}$ & $\mathbf{R}_{6}$ & $\mathbf{R}_{7}$ & $\log I C_{50}$ \\
\hline 1 & & & & $\mathrm{OH}$ & $\mathrm{H}$ & $\mathrm{H}$ & $\mathrm{H}$ & 0.114 \\
\hline 2 & $(O$ in $\mathrm{F}$ & & Prenyl & $\mathrm{H}$ & $\mathrm{H}$ & $\mathrm{OH}$ & Prenyl & -0.046 \\
\hline 3 & $(O$ in $\mathrm{F}$ & & $\mathrm{H}$ & $\mathrm{H}$ & $\mathrm{H}$ & $\mathrm{OH}$ & Prenyl & 0.000 \\
\hline $4 a$ & Prenyl & $\mathrm{OH}$ & $\mathrm{H}$ & $\mathrm{H}$ & $\mathrm{H}$ & \multicolumn{2}{|c|}{$\left(\mathrm{O}\right.$ in $\mathrm{R}_{7}$ ) } & 0.431 \\
\hline 5 & $\mathrm{H}$ & $\mathrm{OH}$ & $\mathrm{H}$ & $\mathrm{H}$ & $\mathrm{H}$ & \multicolumn{2}{|c|}{$\left(O\right.$ in $\left.R_{7}\right)$} & 0.643 \\
\hline 6 & & & & $\mathrm{OH}$ & $\mathrm{OH}$ & $\mathrm{H}$ & $\mathrm{H}$ & 0.279 \\
\hline 7 & Prenyl & $\mathrm{OH}$ & $\mathrm{H}$ & $\mathrm{H}$ & $\mathrm{H}$ & $\mathrm{OH}$ & 0.623 & -0.097 \\
\hline 8 & $\mathrm{H}$ & $\mathrm{H}$ & $\mathrm{H}$ & $\mathrm{H}$ & $\mathrm{OH}$ & $\mathrm{H}$ & 0.204 & 0.623 \\
\hline 9 & $\mathrm{H}$ & $\mathrm{OH}$ & & $\mathrm{OH}$ & $\mathrm{H}$ & $\mathrm{H}$ & 0.505 & 0.204 \\
\hline 10 & $\mathrm{H}$ & $\mathrm{OMe}$ & & $\mathrm{OH}$ & $\mathrm{OH}$ & $\mathrm{H}$ & 0.362 & 0.505 \\
\hline 11 & $\mathrm{H}$ & $\mathrm{OH}$ & & $\mathrm{OH}$ & $\mathrm{OH}$ & $\mathrm{H}$ & 0.544 & 0.362 \\
\hline 12 & $\mathrm{H}$ & & & $\mathrm{OH}$ & $\mathrm{OH}$ & $\mathrm{H}$ & $\mathrm{H}$ & 0.544 \\
\hline 13 & $\mathrm{H}$ & $\mathrm{H}$ & $\mathrm{OH}$ & $\mathrm{OH}$ & $\mathrm{H}$ & $\mathrm{H}$ & 0.690 & 0.544 \\
\hline $14 a$ & $\mathrm{H}$ & $\mathrm{OH}$ & $\mathrm{H}$ & $\mathrm{OH}$ & $\mathrm{H}$ & $\mathrm{H}$ & 0.255 & 1.393 \\
\hline 15 & Prenyl & $\mathrm{OH}$ & $\mathrm{H}$ & $\mathrm{OH}$ & $\mathrm{H}$ & $\mathrm{H}$ & 0.568 & 0.690 \\
\hline 16 & Prenyl & $\mathrm{OH}$ & Prenyl & $\mathrm{OH}$ & $\mathrm{H}$ & $\mathrm{H}$ & 0.820 & 0.255 \\
\hline $17 a$ & $\mathrm{H}$ & $\mathrm{OH}$ & Prenyl & $\mathrm{OH}$ & $\mathrm{H}$ & $\mathrm{H}$ & 1.170 & 0.613 \\
\hline 18 & $\mathrm{OH}$ & $\mathrm{OH}$ & $\mathrm{H}$ & $\mathrm{OH}$ & $\mathrm{H}$ & $\mathrm{H}$ & 0.732 & 0.568 \\
\hline
\end{tabular}




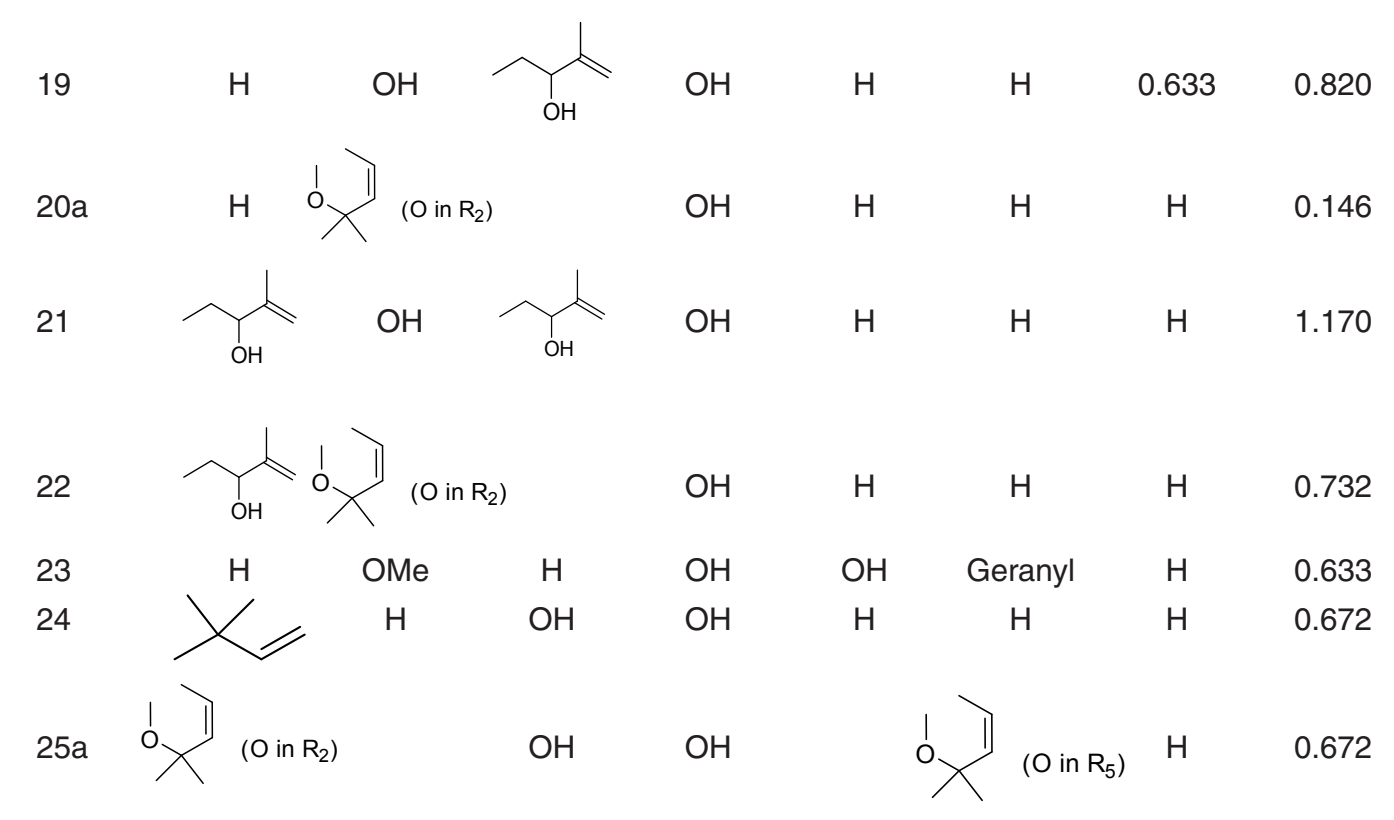

a) Test set

purchased from Aldrich, Acros, and Merck and were used without further purification. All the solvents used in the synthesis were analar and synthesis grade. The solvents used in spectroscopic measurements were spectroscopic grade.

\section{Procedure \\ QSAR Analysis}

In order to find the best calculation method, one of the xanthone compounds (24) was calculated for ${ }^{1} \mathrm{H}$-NMR chemical shift using the semi-empirical method of Austin Model 1 (AM1), Parameterized Model (PM3 and PM6), and Gaussian 09 software. The chemical shift data were then compared to the data of ${ }^{1} \mathrm{H}-\mathrm{NMR}$ from the experiment. AM1, PM3 or PM6 calculation methods which gave the closest values to the experimental data was selected as a method of study throughout the investigation.

\section{Statistical analysis}

The predominant descriptors which affecting the antimalarial activity of the prenylated xanthone analogues were selected according to the correlation analysis by SPSS 23.0 statistical software. In this process, each electronic descriptor was appointed as independent variables and $p \mathrm{IC}_{50}$ as the dependent variable. Moreover, this regression method estimates the values of the regression coefficients by applying least square curve fitting method. The model for QSAR calculation was chosen based on some statistical parameters such as $\mathrm{r}^{2}$, standard estimation of error (SEE), F-ratio between the variance of prediction and observation activity, and PRESS value (predictive residual sum of square), where: PRESS = $\Sigma$ (predicted value-observed value) $)^{2,22}$ in criteria $\mathrm{r}^{2}>$ $0.6,{ }^{23} ;$ SEE $<0.3,{ }^{24} ;$ Fcal/Ftab $\geq 1 .{ }^{25}$ The best-selected model obtained from the previous step was used to predict the $\log \mathrm{IC}_{50}$ of the test set and the model was validated by criteria $r^{2}$ prediction $>0.5 .^{26}$

General procedure for the synthesis of compounds 3,6-dihydroxy-9H-xanthen-9-one (26) and 3,4,6-trihydroxy-9H-xanthen-9-one (27)

A mixture of 2,4-dihydroxybenzoic acid (5 $\mathrm{mmol})$ and resorcinol or pyrogallol $(5 \mathrm{mmol})$ was stirred in Eaton's acid (5 ml) and heated to $80{ }^{\circ} \mathrm{C}$ for $3 \mathrm{~h}$. After the completion of reaction (monitored by TLC), the product was poured into an ice water and the precipitate formed was filtered, washed with water and $5 \% \mathrm{NaHCO}_{3}$. The dried product was purified by silica gel column chromatography with n-hexane/ethyl acetate (gradient 0-30\% ethyl acetate) to afford compound $\mathbf{2 6}$ and $\mathbf{2 7 .}$ 
3,6-dihydroxy-9H-xanthen-9-one (26). Reddish crystals, yield $43 \%$, mp $247{ }^{\circ} \mathrm{C}$; ${ }^{1} \mathrm{H}-\mathrm{NMR}$ (500 MHz, $\mathrm{CDCl}_{3}$ ) $\delta$ (ppm): 7.37 (d, J = 8.5 Hz, 2H), 6.37 (d, J = 8.4 Hz, 2H), 6.35 (s, 2H). HRESIMS calcd. for $\mathrm{C}_{13} \mathrm{H}_{8} \mathrm{O}_{4},[\mathrm{M}+\mathrm{H}]^{+} 229.0522$, found 229.0517.

3,4,6-trihydroxy-9H-xanthen-9-one (27). Reddish crystals, yield $44 \%$, mp $254{ }^{\circ} \mathrm{C}$; ${ }^{1} \mathrm{H}-\mathrm{NMR}$ $\left(500 \mathrm{MHz} \mathrm{CDCl}_{3}\right) \delta$ (ppm): 7.37 (d, J = 8.5 Hz, $2 \mathrm{H}), 6.41$ (d, J=8.4 Hz, 2H), 6.35 (s, 1H). HRESIMS calcd. for $\mathrm{C}_{13} \mathrm{H}_{8} \mathrm{O}_{5},[\mathrm{M}+\mathrm{H}]^{+} 245.0421$, found 245.0411.

\section{Molecular Docking Studies}

The protein crystal structure of the inhibitorbound DHFR was retrieved from Brookhaven Protein
Data Bank (PDB codes: 1J3I). The protein was pretreated before the docking process. Hydrogen atoms were added to the protein structure, and all ionizable residues were set at their default protonation of $\mathrm{pH}$ 7.2 while the ligands were prepared and minimized. During the docking process, the receptor was held rigid while the ligands were allowed to flex during the refinement. A number of polar or nonpolar receptor hotspots for conformer matching starting were set at 500 with the docking tolerance of $0.25 \AA$. The conformations ligands generated from the process was set to 500 within the threshold of relative energy of $20 \mathrm{kcal} / \mathrm{mol}$.

\section{In-vitro Antimalarial activity Assay}

An in-vitroantimalarial assay was conducted against Plasmodium falciparum 3D7 strain which

Table 2: The differences of the ${ }^{1} \mathrm{H}$ NMR chemical shifts by experimental and computational methods $(\delta, \mathrm{ppm})$<smiles>C=CC(C)(C)c1cc(O)c2oc3c(O)cccc3c(=O)c2c1O</smiles>

\begin{tabular}{lcccc}
\hline No Atom H & $\delta$ Experiment & $\delta$ AM1 & $\delta$ PM3 & $\delta$ PM6 \\
\hline 5 & 7.72 & 7.50 & 7.60 & 7.23 \\
11 & 7.53 & 6.22 & 6.10 & 6.01 \\
12 & 7.27 & 6.97 & 6.82 & 6.79 \\
13 & 7.99 & 8.26 & 7.68 & 7.99 \\
18 and 19 & 1.66 & 1.69 & 0.81 & 1.07 \\
20 & 6.47 & 6.03 & 5.87 & 5.92 \\
21 & 5.15 & 5.20 & 4.84 & 4.76 \\
PRESS & 2.13 & 3.53 & 3.56 & \\
\hline
\end{tabular}<smiles>[R]Oc1cccc(O)c1</smiles>

Scheme 1: Reagents and conditions of synthesis: (a) $\mathrm{KHCO}_{3}$, Aquadest, reflux, $4 \mathrm{~h}$; (b) Eaton's acid, heated to $80^{\circ} \mathrm{C}, 3 \mathrm{~h}$ 
sensitive to chloroquine according to the microassay by Rieckmann et al. in 96 well microtitre plates with slight modifications. ${ }^{27}$ For this assay, the compounds were dissolved in DMSO and prepared in a series of concentration, i.e. $100,10,1,0.1$ and $0.01 \mu \mathrm{g} / \mathrm{mL}$ in RPMI-1640 media. Into the sample, Parasitemia and hematocrit, $\pm 1 \%$ and $5 \%$ were added respectively. The culture was incubated for 48 hours at $37^{\circ} \mathrm{C}$, treated with $20 \%$ Giemsa dyes and made it as thin blood layer. After that, the percentage of parasitemia and also the inhibition percentage of $P$. falciparum growth were determined by calculating the number of the infected erythrocytes for every 1000 erythrocytes. Based on the inhibition percentage data, analysis of the correlation between concentrations of the compound with the inhibition percentage was conducted using probit log analysis to determine the $\mathrm{IC}_{50}$.

\section{RESULTS AND DISCUSSION}

\section{Validation method}

Calculation of ${ }^{1} \mathrm{H}-\mathrm{NMR}$ chemical shift of compound 24 using AM1, PM3, and PM6 method showed that AM1 method was the best method, which gives the closest result to the experimental data. This result is clearly shown by the PRESS value of AM1 method (2.13) which is smaller than PM3 (3.53) and PM6 (3.57) as presented in Table 2. Therefore, AM1 method was used to calculate the descriptors of each compound.

\section{Selection of the Best Model}

Statistical multi-linear regression calculation of the descriptors using SPPS give 5 QSAR models as shown in Table 3. It shows that all models depict the linear correlation between biological activity and descriptors as can be seen by the r-value of each

Table 3: Statistical model and parameter of molecular properties and antimalarial activity of xanthone derivatives

\begin{tabular}{|c|c|c|c|c|c|c|c|}
\hline Model & Variables & $\mathbf{r}$ & $\mathbf{r}^{2}$ & $\begin{array}{l}\text { Adjusted } \\
\qquad \mathbf{r}^{2}\end{array}$ & SEE & $\mathbf{F}_{\text {calc }} / \mathbf{F}_{\text {table }}$ & Press \\
\hline 1 & $\begin{array}{l}\text { qC1, q08, qC9, qC12, qC13, } \\
\text { qC14, q015, } \mathrm{E}_{\text {номо }}, \mathrm{E}_{\text {Luмо }}\end{array}$ & 0.942 & 0.888 & 0.787 & 0.148 & 2.921 & 2.791 \\
\hline 2 & $\begin{array}{l}\text { qC1, qO8, qC9, qC12, } \\
q \mathrm{C} 13, \mathrm{qC} 14, \mathrm{qO} 15, \mathrm{E}_{\text {номо }}\end{array}$ & 0.935 & 0.874 & 0.783 & 0.150 & 3.167 & 2.469 \\
\hline 3 & qC1, qO8, qC9, qC12, qC14, qO15, $\mathrm{E}_{\text {номо }}$ & 0.919 & 0.845 & 0.755 & 0.159 & 3.101 & 1.602 \\
\hline 4 & qC1, qO8, qC9, qC12, qC14, qO15 & 0.904 & 0.817 & 0.733 & 0.166 & 3.207 & 0.998 \\
\hline 5 & qO8, qC9, qC12, qC14, qO15 & 0.888 & 0.789 & 0.714 & 0.172 & 3.471 & 0.921 \\
\hline
\end{tabular}

Table 4: The comparison between calculated and experimental antimalarial activity $\left(\log \mathrm{IC}_{50}\right)$ of 5 test set calculated by model 4 and 5

\begin{tabular}{|c|c|c|c|}
\hline \multirow[t]{2}{*}{ Comp } & \multirow{2}{*}{$\begin{array}{l}\text { Experimental } \\
\quad\left(\log \mathrm{IC}_{50}\right)\end{array}$} & \multicolumn{2}{|c|}{ Calculated (log plC $\left.\mathrm{C}_{50}\right)$} \\
\hline & & Model 4 & Model 5 \\
\hline 4 & 0.431 & 0.411 & 0.570 \\
\hline 14 & 1.393 & 1.466 & 1.309 \\
\hline 17 & 0.613 & 0.888 & 0.858 \\
\hline 20 & 0.146 & 0.459 & 0.466 \\
\hline 25 & 0.672 & 0.993 & 0.874 \\
\hline Press & & 0.962 & 0.821 \\
\hline
\end{tabular}

model. Basically, the best model is determined by the number of variable and statistical parameters which belong to that model.

Table 3 also show that model 4 and model 5 are considered to be the best models because those models have the lowest number of variable, the highest Fcalc/tab and the lowest PRESS (predictive residual sum of square) value. Furthermore, model 4 and 5 were used to design of new xanthones derivatives with a better antimalarial activity. The complete QSAR equations of model 4 [1] and 5 [2] are: 
$\log p \mid C_{50}=67.987(q C 1)-37.297(q O 8)-169.104$ $(q C 9)-10.330(q C 12)-127.091(q C 14)+86.740$ (qO15) - 10.827

$\log p \mathrm{IC}_{50}=2.997-29.256(\mathrm{qO} 8)-138.234$ (qC9)

- $6.882(q \mathrm{C} 12)-107.836(\mathrm{qC} 14)+48.764(\mathrm{qO} 15)$

\section{Validation Model}

QSAR equation [1] and [2] were used to predict antimalarial activity $\left(\log p \mathrm{C}_{50}\right)$ of 5 test compounds in order to find the best model in predicting the antimalarial activity of xanthone derivatives (Table 4). The predicted antimalarial activity of 5 test set generated from model 4

\section{Model 4}

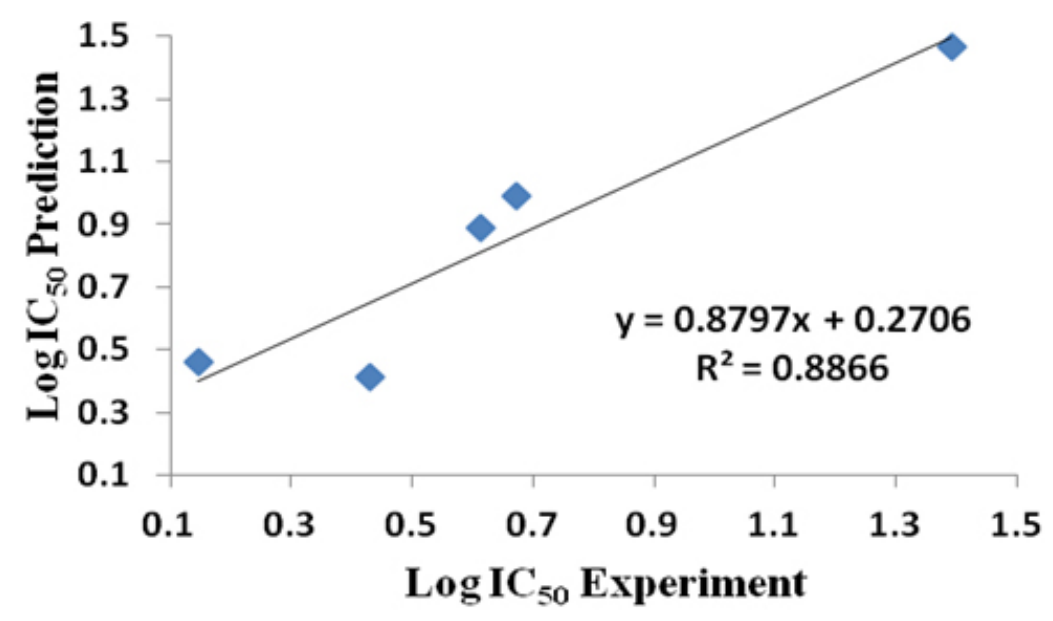

Model 5

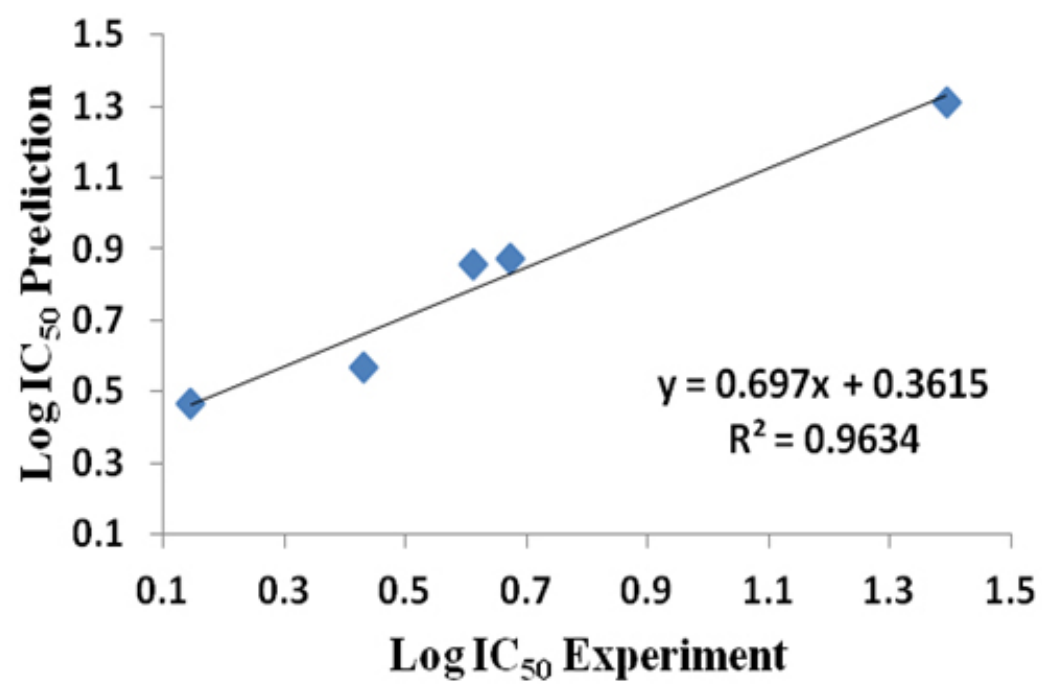

Fig. 1: Plot of experimental result versus predicted antimalarial $I_{50}$ value of 5 test set compounds by model 4 and 5 
and 5 was compared and then plotted with the experimental data by linear regression calculation to see the correlation for each equation, as shown in Fig. 1.

Table 4 shows that PRESS value of model $5(0.821)$ is smaller than model 4 (0.962), which mean model 5 give a closer result to experimental data compared to model 4 . This result is supported by Fig. 1 where model 4 has $r^{2}=0.887$ while model 5 has $r^{2}=0.963$. These numbers mean that there is a significant correlation between an independent variable (in equation 2) and antimalarial activity of xanthone compound. As for model 5 , the $r^{2}$ value of 0.963 means the changing of independent variable (atomic charges of qO8, qC9, qC12, qC14 and qO15) could influence $96.3 \%$ of antimalarial activity $\left(\log \mathrm{IC}_{50}\right)$ of xanthone derivate. Therefore, it can be concluded that model 5 is the best model to design new xanthone compounds with better antimalarial activity.

Furthermore, by introducing the descriptor of qC9, qC14, and qO15 as an active center of antimalarial in xanthone derivatives, it revealed that conjugated double bond with carbonyl group was an important feature on the antimalarial activity. This result showed the similarity with the reported QSAR study conducted et al for chalcone derivatives. ${ }^{28}$

\section{Design of New Antimalarial}

Model 5 as the best QSAR model was used as a guidance to predict the antimalarial activity in the rational design of the new antimalarial compound from xanthone derivatives. $R$ substituents were introduced to the new molecule as a descriptor which will influence the antimalarial activity. From equation 2, it can be shown that in order to get the

Table 5: Design of xanthone derivatives and its predicted antimalarial activity calculated using the best QSAR model

\begin{tabular}{|c|c|c|c|c|c|c|c|c|c|}
\hline Comp & $\mathbf{R}_{1}$ & $\mathbf{R}_{2}$ & $\mathbf{R}_{3}$ & $\mathbf{R}_{4}$ & $\mathbf{R}_{5}$ & $\mathbf{R}_{6}$ & $\mathbf{R}_{7}$ & $\mathbf{R}_{8}$ & $\log I C_{50}$ \\
\hline 26 & $\mathrm{H}$ & $\mathrm{H}$ & $\mathrm{OH}$ & $\mathrm{H}$ & $\mathrm{H}$ & $\mathrm{OH}$ & $\mathrm{H}$ & $\mathrm{H}$ & -0.74 \\
\hline 27 & $\mathrm{H}$ & $\mathrm{H}$ & $\mathrm{OH}$ & $\mathrm{OH}$ & $\mathrm{H}$ & $\mathrm{OH}$ & $\mathrm{H}$ & $\mathrm{H}$ & -1.32 \\
\hline 28 & $\mathrm{OH}$ & $\mathrm{H}$ & $\mathrm{OH}$ & $\mathrm{H}$ & $\mathrm{Cl}$ & $\mathrm{OH}$ & $\mathrm{Cl}$ & $\mathrm{H}$ & -2.14 \\
\hline 29 & $\mathrm{H}$ & $\mathrm{H}$ & $\mathrm{OH}$ & $\mathrm{OH}$ & $\mathrm{OH}$ & $\mathrm{OH}$ & $\mathrm{H}$ & $\mathrm{H}$ & -1.16 \\
\hline 30 & $\mathrm{H}$ & $\mathrm{H}$ & $\mathrm{OH}$ & $\mathrm{OH}$ & $\mathrm{OH}$ & $\mathrm{H}$ & $\mathrm{OH}$ & $\mathrm{Cl}$ & -2.69 \\
\hline 31 & $\mathrm{H}$ & $\mathrm{H}$ & $\mathrm{OH}$ & $\mathrm{OH}$ & $\mathrm{OH}$ & $\mathrm{H}$ & $\mathrm{OH}$ & & -4.09 \\
\hline 32 & $\mathrm{H}$ & $\mathrm{H}$ & $\mathrm{OH}$ & $\mathrm{OH}$ & $\mathrm{OH}$ & $\mathrm{H}$ & $\mathrm{OH}$ & $\mathrm{NO}_{2}$ & -5.17 \\
\hline 33 & $\mathrm{OH}$ & $\mathrm{H}$ & $\mathrm{H}$ & $\mathrm{H}$ & $\mathrm{H}$ & $\mathrm{OH}$ & $\mathrm{Cl}$ & $\mathrm{H}^{2}$ & -0.54 \\
\hline 34 & $\mathrm{OH}$ & $\mathrm{H}$ & $\mathrm{H}$ & $\mathrm{H}$ & $\mathrm{H}$ & $\mathrm{Cl}$ & $\mathrm{OH}$ & $\mathrm{H}$ & -0.76 \\
\hline 35 & $\mathrm{H}$ & $\mathrm{H}$ & $\mathrm{H}$ & $\mathrm{H}$ & $\mathrm{H}$ & $\mathrm{Cl}$ & $\mathrm{OH}$ & $\mathrm{H}$ & -2.40 \\
\hline 36 & $\mathrm{OH}$ & Prenyl & $\mathrm{OH}$ & $\mathrm{H}$ & $\mathrm{H}$ & $\mathrm{Cl}$ & $\mathrm{OH}$ & Prenyl & -1.13 \\
\hline 37 & $\mathrm{OH}$ & Prenyl & $\mathrm{OH}$ & Prenyl & $\mathrm{H}$ & $\mathrm{Cl}$ & $\mathrm{OH}$ & $\mathrm{NO}_{2}$ & -4.39 \\
\hline 38 & $\mathrm{OH}$ & $\mathrm{H}$ & $\mathrm{H}$ & $\mathrm{H}$ & $\mathrm{H}$ & $\mathrm{H}$ & $\mathrm{OH}$ & $\mathrm{SO}_{3}^{2} \mathrm{H}$ & -8.76 \\
\hline 39 & $\mathrm{H}$ & $\mathrm{H}$ & $\mathrm{H}$ & $\mathrm{H}$ & $\mathrm{H}$ & $\mathrm{H}$ & $\mathrm{OH}$ & $\mathrm{SO}_{3}^{3} \mathrm{H}$ & -9.31 \\
\hline 40 & $\mathrm{H}$ & $\mathrm{H}$ & $\mathrm{H}$ & $\mathrm{H}$ & $\mathrm{H}$ & $\mathrm{OH}$ & $\mathrm{OH}$ & $\mathrm{SO}_{3}^{3} \mathrm{H}$ & -10.83 \\
\hline 41 & $\mathrm{H}$ & $\mathrm{H}$ & $\mathrm{H}$ & $\mathrm{H}$ & $\mathrm{SO}_{3} \mathrm{H}$ & $\mathrm{OH}$ & $\mathrm{OH}$ & $\mathrm{SO}_{3}^{3} \mathrm{H}$ & -21.18 \\
\hline 42 & $\mathrm{OH}$ & $\mathrm{H}$ & $\mathrm{H}$ & $\mathrm{H}$ & $\mathrm{SO}_{3}^{3} \mathrm{H}$ & $\mathrm{OH}$ & $\mathrm{OH}$ & $\mathrm{SO}_{3} \mathrm{H}$ & -19.97 \\
\hline 43 & $\mathrm{OH}$ & $\mathrm{H}$ & $\mathrm{H}$ & $\mathrm{H}$ & $\mathrm{NO}_{2}^{3}$ & $\mathrm{OH}$ & $\mathrm{OH}$ & $\mathrm{NO}_{2}^{3}$ & -10.42 \\
\hline
\end{tabular}


best antimalarial activity, atomic charges of $08, \mathrm{C9}$, $\mathrm{C} 12$ and $\mathrm{C} 14$ should have a positive charge while the atomic charge of $\mathrm{O} 15$ should be negative. A positive charge in atom $\mathrm{C} 12$ can be obtained by adding electronegative substituents or donating electrons groups such as hydroxyl and halogen. Since C9 and C14 were C quarter atom which cannot be added with any $R$ substituents, so the substituents must be bonded in $\mathrm{C} 10$ and $\mathrm{C} 13$. In order to get a positive partial charge of $\mathrm{C} 9$ and $\mathrm{C} 14$, withdrawing electron group could be added in $\mathrm{C} 10$ and $\mathrm{C} 13$ since the resonance could make an atomic charge of atom C9 and C14 becomes more positive.

The designed new antimalarial compounds of xanthone derivatives based on the best QSAR model were listed in Table 5. Indeed, this study shows that $R$ substituents variation gives a difference antimalarial activity. It can be seen in Table 5 that there is a very significant change of the predicted antimalarial activity occurred when substituent was changed to $\mathrm{SO}_{3} \mathrm{H}$ and $\mathrm{NO}_{2}$ at $\mathrm{C} 10$ and $\mathrm{C} 13$. In addition, removing of $\mathrm{SO}_{3} \mathrm{H}$ from the compound gives significant influence in decreasing the antimalarial activity. This result is similar to the previously reported study, ${ }^{28}$ that substitution of $\mathrm{SO}_{3} \mathrm{H}$ functional group is able to provide the best antimalarial activity towards chalcone compound. Meanwhile, electron donating group $\mathrm{OH}$ is a substituent that also gives the significant influence which leads to the better antimalarial activity.

Synthesis and an in-vitro antimalarial activity assay of compound $\mathbf{2 6}$ and $\mathbf{2 7}$ against chloroquinesensitive 3D7 strain have been successfully conducted. The experimental antimalarial activity of $\mathbf{2 6}$ and $\mathbf{2 7}$ are close to the results from the QSAR analysis (Table 6). This result proves the accuracy of the generated QSAR equation to predict the antimalarial activity of xanthone derivatives. Also, the antimalarial activity of compound $\mathbf{2 6}$ and $\mathbf{2 7}$ could be categorized as a good antimalarial although their $\mathrm{IC}_{50}$ are slightly higher than the chloroquine as a control.

The active synthesized compound 26 and 27 as antimalarial was docked to the active site of the $P$. falciparum DHFR crystal structure to confirm their mechanism as an antimalarial drug. Thus, the protein crystal structure of DHFR (1J3I: $2.33 \AA$ ) was retrieved from Brookhaven Protein Data Bank. P. falciparum dihydrofolate reductases- thymidylate synthase (PfDHFR-TS) is an important target of antimalarial drugs. ${ }^{29}$ The inhibition of this enzyme could prevent the dTMP production and DNA synthesis since it involved in the catalysis sequential reactions in the thymidylate cycle. ${ }^{30}$ The docking studies of compounds $\mathbf{2 6}$ and $\mathbf{2 7}$ displayed favorable binding

Table 6: The antimalarial activity $\left(\mathrm{IC}_{50}\right)$ of compound 26 and 27 based on experimental assay and QSAR analysis

\begin{tabular}{|c|c|c|c|c|}
\hline \multirow[t]{2}{*}{ Comp } & \multicolumn{2}{|c|}{ QSAR Analysis } & \multicolumn{2}{|c|}{ Data Experiment In vitro (3D7) } \\
\hline & $\log p \mid C_{50}$ & $p l C_{50}(\mu \mathrm{g} / \mathrm{ml})$ & $\mathrm{IC}_{50}(\mu \mathrm{g} / \mathrm{ml})$ & $\mathrm{IC}_{50}(\mu \mathrm{M})$ \\
\hline 26 & -0.74 & 0.182 & 0.162 & 0.71 \\
\hline 27 & -1.32 & 0.048 & 0.027 & 0.11 \\
\hline $\mathrm{CQ}$ & - & - & 0.012 & 0.04 \\
\hline
\end{tabular}

Table 7: Docking interaction of compounds 26 and 27 in Pf-DHFR-TS

\begin{tabular}{llc}
\hline Comp & Binding interaction & $\begin{array}{c}\text { Wild-type Pf-DHFR-TS } \\
\text { Binding Energy }\end{array}$ \\
\hline 26 & Ala16, Ser108, Phe58, Asp54, Leu46, Cys15 & -27.586 \\
27 & Ala16, Ser108, Phe58, Met55, Leu46, Tyr170 & -30.991 \\
WR99210 & Ala16, Ser108, Phe58, Met55, Asp54, lle14, lle164, Trp48, and Thr185 & $-54,3237$ \\
\hline
\end{tabular}


affinity towards DHFR with -cDOCKER energy shown in Table 7 and the docking interaction showed in Figure 2.
Docking studies revealed the binding site of 26 and $\mathbf{2 7}$ form interactions with Ala16, Ser108, Asp54, Met55, and Phe58 amino acid which is the
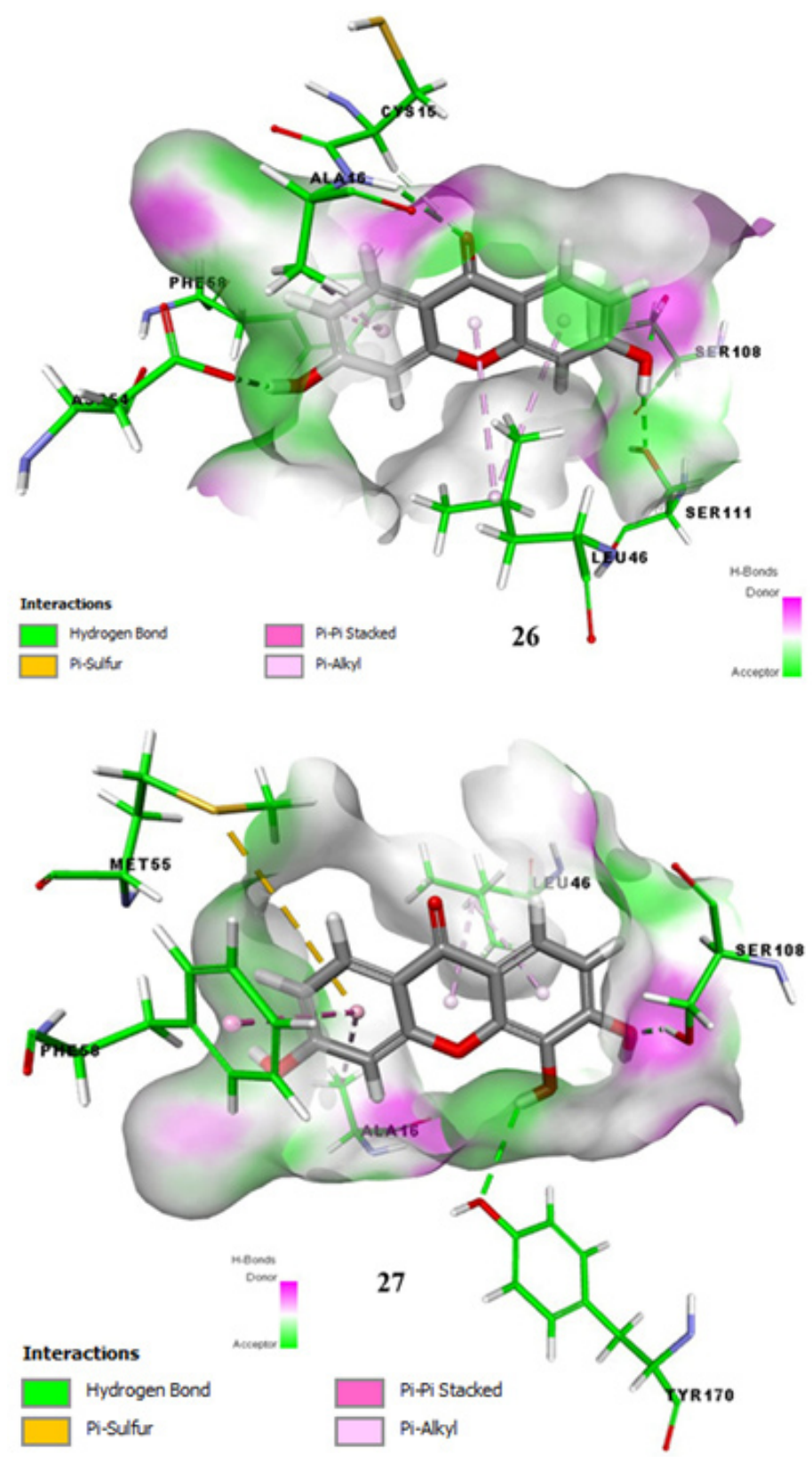

Fig. 2: Predicted binding mode from docking simulation of 26 and 27 into the active site of $P$. falciparum DHFR-TS (PDB ID: 1J3I). The coloring atom for the compound is in order as follows: carbons in gray, oxygen in red, nitrogen in blue, and hydrogen in white. The green line indicates hydrogen-bonding interaction with distance ascribed in angstroms, $\AA$. 
crucial interactions for antimalarial activity based on the binding interactions displayed by the ligand co-crystal of WR99210 (1,3,5-triazine containing pre-clinical molecule as Pf-DHFR-TS inhibitor), a potent antimalarial compound. On the other hand, 26 and 27 are well-positioned in the DHFR active site, constituting of residues Ile14, Ala16, Trp48, Asp54, Met55, Phe58, Ser108, lle164 and Thr185 (Figure 2).

\section{CONCLUSION}

A semi-empirical molecular orbital calculation AM1 was used to study the correlation between structure and the antimalarial activity of xanthone derivatives series. Correlation of antimalarial activity with the structure has shown by atom charge of qC9, qC12, qC14 and qO15 as the active site of antimalarial. Antimalarial activity of the synthesized compounds $\mathbf{2 6}$ and $\mathbf{2 7}$ proved the relevancies between QSAR calculation and the experimental $\mathrm{IC}_{50}$ data. Molecular docking showed the binding interaction of $\mathbf{2 6}$ and $\mathbf{2 7}$ with the crucial amino acid for antimalarial activity.

\section{ACKNOWLEDGMENT}

Authors gratitude to Ministry of Research, Technology, and Higher Education-Indonesia for the financial support of this work through competing for research project grant, contract number 92A/ KONTRAK-PENELITIAN BATCH II/010/KM/2016, date February 22 ${ }^{\text {nd }}, 2016$ (Skim Hibah Bersaing). Gratitude also for Austrian Indonesian Centre (AIC), Universitas Gadjah Mada who provided the gaussian 09 licenses. The authors also acknowledge the Discovery studio 3.1 by CADD Laboratory, Faculty of Pharmacy, Universiti Kebangsaan Malaysia, for the Discovery Studio 3.1 licenses.

\section{REFERENCES}

1. World Health Organization. WHO Press, 2015. [Online] Available from http://www.who.int/ malaria/publications/world-malaria-report2015/report/en/ [Accessed on 20th August 2016].

2. Fidock, D, A.; Rosenthal, P, J.; Croft, S, L.; Brun, R.; Nwaka, S. Nat. Rev. Drug Discov. 2004, 3, 509-520.

3. Ashley, E, A.; Dhorda, M.; Fairhurst, R, M.; Amaratunga, C.; Lim, P.; Suon, S.; Sreng, S.; Anderson, J, M.; Mao, S.; Sam, B.; Sopha, C.; Chuor, C, M.; Nguon, C.; Sovannaroth, S.; Pukrittayakamee, S.; Jittamala, P.; Chotivanich, K.; Chutasmit, K.; Suchatsoonthorn, C.; Runcharoen, R.; Hien, T, T.; Thuy-Nhien, N, T.; Thanh, N, V.; Phu, N, H.; Htut, Y.; Han, K, T.; Aye, K, H.; Mokuolu, O, A.; Olaosebikan, R, R.; Folaranmi, O, O.; Mayxay, M.; Khanthavong, M.; Hongvanthong, B.; Newton, P, N.; Onyamboko, M, A.; Fanello, C, I.; Tshefu, A, K.; Mishra, N.; Valecha, N.; Phyo, A, P.; Nosten, F.; Yi, P.; Tripura, R.; Borrmann, S.; Bashraheil, M.; Peshu, J.; Faiz, M, A.; Ghose, A.; Hossain, M, A.; Samad, R.; Rahman, M, R.; Hasan, M, M.; Islam, A.; Miotto, O.; Amato, R.; Maclnnis, B.; Stalker, J.; Kwiatkowski, D, P.; Bozdech,
Z.; Jeeyapant, A.; Cheah, P, Y.; Sakulthaew, T.; Chalk, J.; Intharabut, B.; Silamut, K.; Lee, S, J.; Vihokhern, B.; Kunasol, C.; Imwong, M.; Tarning, J.; Taylor, W, J.; Yeung, S.; Woodrow, C, J.; Flegg, J, A.; Das, D.; Smith, J.; Venkatesan, M.; Plowe, C, V.; Stepniewska, K.; Guerin, P, J.; Dondorp, A, M.; Day, N, P.; White, N, J. Engl. J. Med. 2014, 371, 411-423.

4. Upegui, Y.; Robledo, S, M.; Romero, J, F, G.; Quiñones, W.; Archbold, R.; Torres, F.; Escobar, G.; Nariño, B.; Echeverri, F. Phytother. Res. 2015, 29, 1195-1201.

5. Lyles, J, T.; Negrin, A.; Khan, S, I.; He, K.; Kennelly, E, J. Planta. Med. 2014, 80, 676681.

6. Na, Z.; Song, Q.; Hu, H. Rec. Nat. Prod. 2013, 7, 220-224.

7. Yuanita, E.; Pranowo, H, D.; Jumina, J.; Mustofa, M. Asian. J. Pharm. Clin. Res. 2016, 9, 180-185.

8. Yang, Z, M.; Huang, J.; Qin, J, K.; Dai, Z, K.; Lan, W, L.; Su, G, F.; Tang, H.; Yang, F. Eur. J. Med. Chem. 2014, 85, 487-497.

9. Fei, X.; Jo, M.; Lee, B.; Han, S, B.; Lee, K.; Jung, J, K.; Seo, S, Y.; Kwak, Y, S. Bioorg. Med. Chem. Lett. 2014, 24, 2062-2065.

10. Castanheiro, R, A, P.; Silva, A, M, S.; Campos, 
N, A, N.; Nascimento, M, S, J.; Pinto, M, M, M. Pharmaceuticals. 2009, 2, 33-43.

11. Luo, L.; Qin, J, K.; Dai, Z, K.; Gao, S, H. J. Serb. Chem. Soc. 2013, 78, 1301-1308.

12. Seca; Ana, M, L.; Leal, S, B.; Pinto, D, C, G, A.; Barreto, M, C.; Silva, A, M, S. Molecules. 2014, 19, 8317-8333.

13. Lee, B, W.; Lee, J, H.; Lee, S, T.; Lee, H, S.; Lee, W, S.; Jeong, T, S.; Park, K, H. Bioorg. Med. Chem. Lett. 2005, 15, 5548-5552.

14. Tang, Z, Y.; Xia, Z, X.; Qiao, S, P.; Jiang, C.; Shen, G, R.; Cai, M, X.; Tang, X, Y. Fitoterapia. 2015, 102, 109-114.

15. Zhou, Z, B.; Zhang, Y, M.; Luo, J, G.; Kong, L, Y. Phytochem. Lett. 2016, 15, 215-219.

16. Deng, Y, X.; Pan, S, L.; Zhao, S, Y.; Wu, M, Q.; Sun, Z, Q.; Chen, X, H.; Shao, Z, Y. Fitoterapia. 2012, 83, 1548-1552.

17. Itoh, T.; Ohguchi, K.; linuma, M.; Nozawaa, Y.; Akao, Y. Bioorg. Med. Chem. 2008, 16, 4500-4508.

18. Mahendran, G.; Manoj, M.; Murugesh, E.; Kumar, R, S.; Shanmughavel, P.; Prasad, K, J, R.; Bai, V, N. Phytomedicine. 2014, 21, 1237-1248.

19. Amanatie; Jumina; Mustofa; Hanafi, M.; Armunanto, R. Indo. J. Chem. 2010, 10, 357362.

20. Hay, A, E.; Helesbeux, J, J.; Duval, O.;
Labaied, M.; Grellier, P.; Richomme, P. Life. Sci. 2004, 75, 3077-3085.

21. Marti, G.; Eparvier, V.; Litaudon, M.; Grellier, P.; Gueritte, F. Molecules, 2010, 15, 71067114.

22. Podunavac-Kuzmanovic, S, O.; Cvetkovic, D, D.; Barna, D, J. Int. J. Mol. Sci. 2009, 10, 1670-1682.

23. Golbraikh, A.; Shen, M.; Xiao, Z.; Xiao, Y, D.; Lee, K, H.; Tropsha, A. J. Comput. Aided. Mol. Des. 2003, 17, 241-253.

24. Modak, V, P.; Pathak, H.; Thayer, M.; Singer, S, J.;Wyslouzil, B, E. Phys. Chem. Chem. Phys. 2013, 15, 6783-6795.

25. Motta, L, F.; Almeida, W, P. Int. J. Drug. Disc. 2011, 3, 100-117.

26. Frimayanti, N.; Yam, M, L.; Lee, H, B.; Othman, R.; Zain, S, M.; Rahman, N, A. Int. J. Mol. Sci. 2011, 12, 86268644.

27. Rieckmann, K, H.; Sax, L, J.; Campbell, G, H.; Mrema, J, E. Lancet. 1978, 311, 22-23

28. Syahri, J.; Purwono, B.; Armunanto, R. Int. J. Pharm. Sci. Rev. Res. 2016, 36, 7176.

29. Yuvaniyama, J.; Chitnumsub, P.; Kamchonwongpaisan, S.; Vanichtanankul, J.; Sirawaraporn, W.; Taylor, P.; Walkinshaw, M, D.; Yuthavong, Y. Nat. Struct. Biol. 2003, 10, 357-365.

30. Ferone, R. Bull. World. Health. Organ. 1977, 55, 291-298. 